\title{
MORTALITAS LARVA HAMA KUPU KUNING (Eurema sp.) AKIBAT PEMBERIAN EKSTRAK BIJI NONA SEBRANG (Annona glabra L.)
}

\author{
Mortality of Yellow Butterfly (Eurema sp.) Larvae Due to Pond Apple (Annona glabra \\ L.) Seed Extract Application
}

\section{Ujang W. Darmawan ${ }^{1}$ dan/and Agus Ismanto ${ }^{2}$}

${ }^{1}$ Pusat Penelitian dan Pengembangan Hutan

Jl. Gunung Batu No. 5 Kotak Pos 165 Bogor 16610, Jawa Barat, Indonesia

Tlp. : (0251) 8633234; Fax. : (0251) 8638111

${ }^{2}$ Pusat Penelitian dan Pengembangan Hasil Hutan

Jl. Gunung Batu No. 5, Po. Box. 182, Bogor 16610, Telp. 0251 - 8633378 Fax.0251 - 8633413

Email: ujdarmawan@ymail.com; ismanto_agus@yahoo.com

Tanggal diterima : 27 November 2014; Tanggal direvisi : 14 November 2016; Tanggal disetujui : 5 Desember 2016

\section{ABSTRACT}

Family Annonaceae known by its potential as source of botanical insectiside. Annona glabra L. (Annonaceae) has not been widely studied. This research aimed to find out the effectiveness of A. glabra seed extract against yellow butterfly (Eurema sp. larvae. The experiment was conducted at laboratory level. Seed extract was given by oral (feeding) and direct contact (spraying). GCMS analysis showed that the main active compounds of A. glabra seed extract were 9-octadecenoic acid (oleic acid) and 13-docosenoic acid or erucic acid. It exposed effective leading mortality against Eurema $s p$. larvae. Lethal concentration $L C_{50}$ value of oral and spraying treatments were 8.37 $\mathrm{mg} / \mathrm{ml}$ and $3.92 \mathrm{mg} / \mathrm{ml}$ respectively.

\section{Keywords: Annona glabra, botanical insecticide, Eurema sp. and mortality}

\begin{abstract}
ABSTRAK
Family Annonaceae sudah diketahui memiliki potensi sebagai pestisida nabati. Nona sebrang (Annona glabra L.) adalah salah satu jenis dari famili Annonaceae yang belum banyak dipelajari. Penelitian ini bertujuan untuk menguji efektivitas ekstrak biji nona sebrang terhadap mortalitas larva kupu-kupu kuning (Eurema sp.). Penelitian dilakukan pada tingkat laboratorium. Ekstrak biji nona sebrang diberikan dengan cara oral (pemberian pakan) dan kontak langsung (penyemprotan) ke serangga uji. Hasil analisis GCMS menunjukkan bahwa senyawa aktif utama penyusun ekstrak biji nona sebrang adalah 9-octadecenoic acid (asam oleat) dan 13-docosenoic acid atau erucic acid. Senyawa tersebut terbukti efektif mematikan ulat larva Eurema sp. Nilai konsentrasi lethal $\left(L C_{50}\right)$ untuk perlakuan penyemprotan pakan dan penyemprotan langsung ke larva masing-masing adalah $8,37 \mathrm{mg} / \mathrm{ml}$ dan 3,92 $\mathrm{mg} / \mathrm{ml}$.
\end{abstract}

Kata kunci: Annona glabra, Eurema sp., insektisida nabati dan mortalitas

\section{PENDAHULUAN}

Sengon (Falcataria moluccana (Miq.) Barneby \& J.W. Grimes) merupakan salah satu jenis pohon penghasil kayu yang sangat diminati oleh pasar. Di Indonesia, tanaman ini telah dibudidayakan dalam skala besar seperti hutan tanaman industri maupun dalam skala kecil seperti pada hutan rakyat. Sekitar 328 juta batang tanaman sengon sudah dibudidayakan yang umumnya tersebar di pulau Jawa (BPS, 2013). Angka ini jauh lebih besar dibandingkan dengan jenis tanaman lainnya seperti jati (Tectona grandis L.), mahoni (Swietenia spp.) maupun jenis tanaman kehutanan lainnya.

Salah satu persoalan yang dihadapi dalam pengusahaan atau budidaya tanaman ini adalah adanya serangan hama. Beberapa hama yang berasosiasi dengan tanaman ini diantaranya adalah hama kumbang penggerek batang Xystrocera festiva Thompson, ulat kantong dan kupu kuning Eurema spp. Larva Eurema spp. merupakan hama yang merusak tanaman dengan cara memakan jaringan daun (defoliator). 
Beberapa spesies dari kelompok ini diantaranya adalah E. blanda, E. hecabe, E. alitha dan E. sari. Serangan pada tanaman muda dan semai dapat menyebabkan defoliasi (kehilangan daun) dan kematian tanaman (Tuhumury, 2007).

Beberapa percobaan pengendalian hama secara nabati yang sudah dilakukan adalah ekstrak biji bintaro (Utami, 2010) dan mimba (Ogah \& Ogbodo, 2012). Selain 2 jenis bahan tersebut, potensi pestisida nabati dapat berasal dari tanaman lain seperti dari kelompok Annonaceae. Setidaknya terdapat 42 spesies tumbuhan dari famili ini yang menunjukkan kemampuan dalam mengendalikan sekitar 60 jenis hama (Krinski et al., 2014).

Salah satu tumbuhan yang tergolong dalam famili Annonaceae adalah nona sebrang (Annona glabra L.). Dibandingkan dengan anggota famili Annonaceae yang lain, tanaman ini masih sangat sedikit referensinya yang berkaitan dengan kemampuannya dalam mengendalikan hama, oleh karena itu perlu dilakukan pengujian ekstrak biji nona sebrang ( $A$. glabra) dalam mengendalikan hama kupu kuning (Eurema sp.). Tujuan penelitian adalah mengetahui pengaruh ekstrak biji nona sebrang terhadap mortalitas larva dari hama kupu kuning dan menentukan konsentrasi yang mampu menimbulkan kematian serangga uji sebanyak $50 \%\left(\mathrm{LC}_{50}\right)$.

\section{METODOLOGI}

\section{A. Bahan dan Alat}

Bahan yang digunakan adalah biji buah nona sebrang (A. glabra), akuades, metanol teknis, daun sengon, larva Eurema sp. instar tiga, tisu. Alat yang digunakan adalah blender, oven, rotary vacuum evaporator, gelas erlenmeyer, cawan petri dan semprotan.

\section{B. Persiapan Ekstrak}

Biji A. glabra dikeringanginkan tanpa terpapar dengan sinar matahari langsung, kemudian biji yang telah kering dihaluskan menggunakan blender untuk menghasilkan ukuran serbuk 40-60 mesh. Sebanyak $200 \mathrm{~g}$ serbuk yang dihasilkan kemudian diekstraksi menggunakan metode maserasi (perendaman) menggunakan pelarut metanol selama 3 x 24 jam. Filtrat yang dihasilkan kemudian disaring dan dipekatkan dengan rotary vacum evaporator menghasilkan ekstrak biji buah nona sebrang.

\section{Pengujian Kandungan Kimia Ekstrak}

Ekstrak biji buah nona sebrang yang berupa pekatan kemudian dianalisis untuk mengetahui kandungan kimia di dalamnya menggunakan metode Gas Chromatography Mass Spectrometry (GCMS). Pengujian dilakukan di laboratorium terpadu Pusat Penelitian dan Pengembangan Hasil Hutan Bogor.

\section{Efikasi Serangga Uji}

Sampel serangga uji yang digunakan adalah larva (ulat) Eurema sp. instar tiga. Percobaan dilakukan dengan menggunakan Rancangan Acak Lengkap dengan perlakuan beberapa taraf konsentrasi ekstrak ekstrak. Pengujian dilakukan menggunakan dua cara, yaitu pemberian pakan secara oral dan penyemprotan ke tubuh serangga uji.

Pengujian pertama, pemberian pakan dilakukan dengan cara mencelupkan pakan berupa daun sengon sebanyak 3 sub helai ke dalam larutan biji buah nona sebrang dengan konsentrasi $0 \mathrm{mg} / \mathrm{ml}, 3,125 \mathrm{mg} / \mathrm{ml}, 6,25 \mathrm{mg} / \mathrm{ml}$, $12,5 \mathrm{mg} / \mathrm{ml}, 25 \mathrm{mg} / \mathrm{ml}, 50 \mathrm{mg} / \mathrm{ml}$ dan $100 \mathrm{mg} / \mathrm{ml}$ selama 3 detik. Daun yang telah dicelupkan dalam larutan ekstrak sesuai perlakuan konsentrasi kemudian dikeringanginkan dan dimasukkan ke dalam cawan petri dengan diameter $9 \mathrm{~cm}$ yang dialasi kertas saring. Kertas saring dimaksudkan agar cawan petri tidak lembab atau basah karena kotoran ulat. Selanjutnya serangga uji sebanyak 10 ekor ulat dimasukkan ke dalam cawan petri dan ditutup. Setiap perlakuan diulang 3 kali.

Pengujian kedua, penyemprotan ekstrak biji nona sebrang sesuai perlakuan dosis $0 \mathrm{mg} / \mathrm{ml}$, $6,25 \mathrm{mg} / \mathrm{ml}, 12,5 \mathrm{mg} / \mathrm{ml}, 25 \mathrm{mg} / \mathrm{ml}, 50 \mathrm{mg} / \mathrm{ml}$ dan $100 \mathrm{mg} / \mathrm{ml}$ sebanyak $0,5 \mathrm{ml}$. langsung ke tubuh serangga uji dan didiamkan selama 2 menit. Setelah itu serangga uji dipindahkan ke dalam cawan petri secara hati-hati menggunakan kuas halus. Selanjutnya 3 sub helai daun sengon segar sebagai pakan dimasukkan kedalam cawan pertri dan ditutup. Variasi konsentrasi yang digunakan pada percobaan dimaksudkan untuk menentukan nilai $\mathrm{LC}_{50}$ dari yang paling kecil dan meningkat sesuai kelipatannya. Penentuan konsentrasi larutan ekstrak biji nona sebrang menggunakan formula sebagai berikut:

$$
\text { Konsentrasi }=\frac{\text { Berat }(m g)}{\text { Volume }(m l)} \times 100 \%
$$


Pengamatan dimulai 24 jam setelah perlakuan dan diulang setiap 24 jam berikutnya sampai 6 kali pengamatan. Setiap hari serangga uji yang mati diambil dari dalam cawan petri dan kertas saring diganti dengan yang baru. Selain itu pakan yang tersedia juga diganti dengan pakan yang baru tanpa perlakuan (daun segar). Variabel yang diamati adalah jumlah ulat yang mati pada setiap waktu pengamatan.

\section{E. Analisis Data}

Data dianalisis menggunakan sidik ragam untuk mengetahui perbedaan respon perlakuan terhadap mortalitas. Analisis probit dilakukan untuk menentukan tingkat konsentrasi letal 50\% $\left(\mathrm{LC}_{50}\right.$ ) (Zhu et al., 2014). Nilai $\mathrm{LC}_{50}$ diperoleh dengan cara membuat regresi antara "log konsentrasi" dengan "nilai probit dari mortalitas yang telah terkoreksi dengan kontrolnya". Formula untuk mengkoreksi mortalitas mengikuti formula Abbots sebagai berikut (De Oliveira et al., 2010):

$$
\mathrm{Ma}=\frac{\mathrm{Mt}-\mathrm{Mc}}{100-\mathrm{Mc}} \times 100 \%
$$

$$
\begin{aligned}
& \mathrm{Ma}=\text { Mortalitas terkoreksi } \\
& \mathrm{Mt}=\text { Mortalitas teramati } \\
& \mathrm{Mc}=\text { Mortalitas pada kontrol }
\end{aligned}
$$

Persamaan regresi yang terbentuk berupa $y=$ $\mathrm{a}+\mathrm{bx}$, dimana $\mathrm{y}=$ nilai probit dan $\mathrm{x}=\log$ konsentrasi. Nilai $\mathrm{LC}_{50}$ ditentukan berdasarkan persamaan $z=(5-a) / b$. Nilai dari antilog " $z$ " tersebut menunjukkan besarnya $\mathrm{LC}_{50}$.

\section{HASIL DAN PEMBAHASAN}

\section{A. Hasil}

Hasil analisis kromatogram ekstrak biji nona sebrang menunjukkan senyawa kimia yang tertinggi adalah 9-octadecenoic acid (asam oleat) dan 13-Docosenoic acid atau Erucic acid dengan masing-masing kandungannya sebesar 35,21\% dan $12,88 \%$. Kedua senyawa ini merupakan senyawa utama yang bersifat toksit terhadap serangga uji. Oleh karena itu, kedua senyawa ini potensial sebagai bahan senyawa aktif untuk insektisida nabati. Komponen kimia ekstrak biji nona sebrang dan hasil analisis kromatogram disajikan pada Tabel 1 dan Gambar 1.

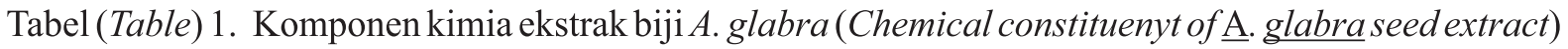

\begin{tabular}{llr}
\hline No & \multicolumn{1}{c}{ Komponen (Component) } & $\begin{array}{c}\text { Persen } \\
(\text { Percent })(\%)\end{array}$ \\
\hline 1. & 9-Octadecenoic acid (Z)- (CAS) Oleic acid & 35,21 \\
2. & 13-Docosenoic acid, methyl ester (CAS) METHYL 13-DOCOSENOATE & 12,88 \\
3. & 9-Octadecenamide, (Z)-(CAS) OLEOAMIDE & 8,08 \\
4. & Heptadec-8-ene & 4,39 \\
5. & 13-Oxabicyclo[10.1.0]tridecane (CAS) poxycyclododecane & 3,79 \\
6. & Octadecane, 1-chloro- (CAS) 1-Chlorooctadecane & 3,28 \\
7. & 3-HEXADECYLOXYCARBONYL-5-(2-HYDROXYETHYL)-4-METHYLIMIDAZOL & 3,22 \\
\hline
\end{tabular}

Keterangan(Remark): Hasil identifikasi GCMS di Pusat Penelitian dan Pengembangan Hasil Hutan, Bogor (Identification using GCMS at Center of Forest Product Research and Development, Bogor) 


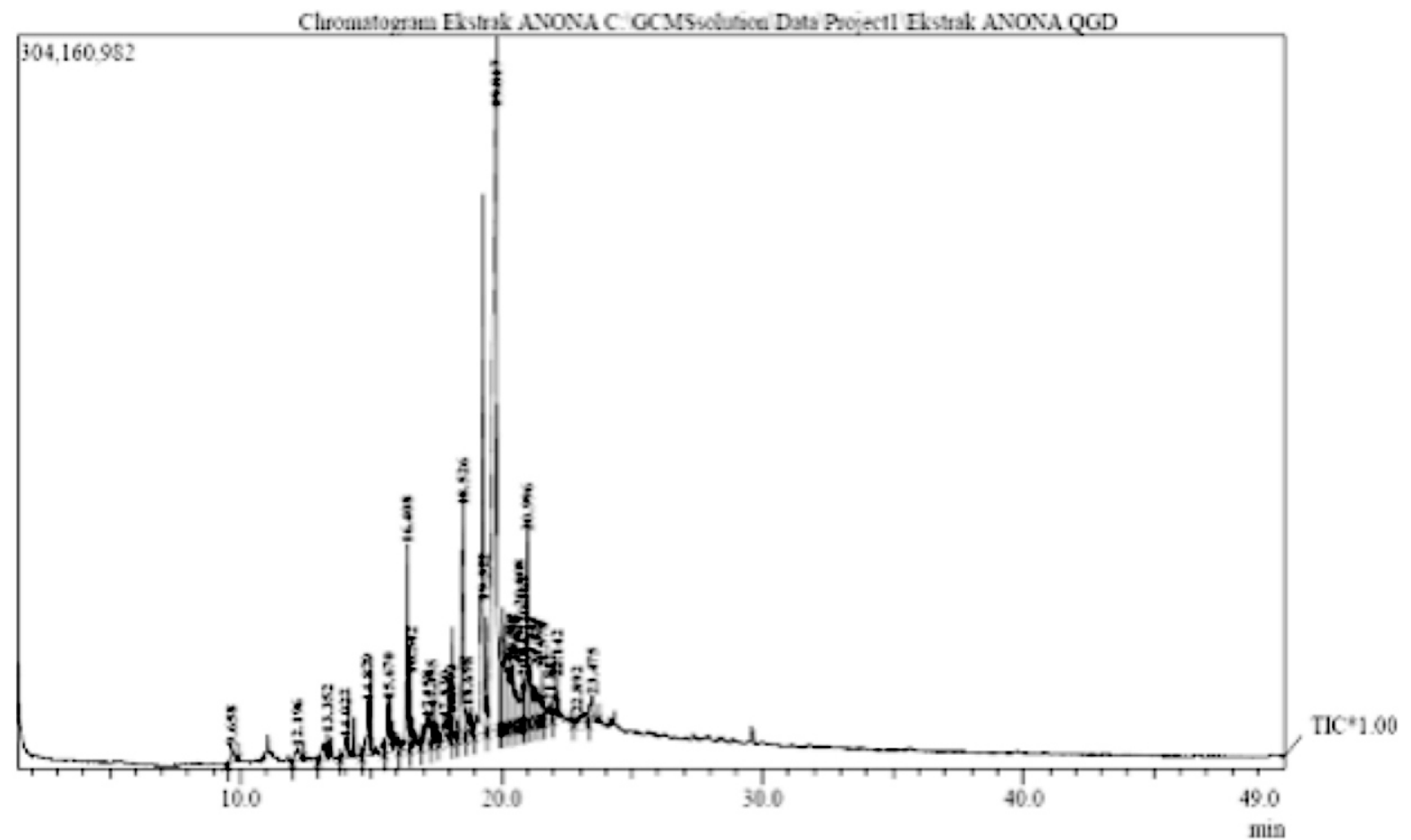

Gambar (Figure) 1. Kromatogram ekstrak biji nona sebrang (Chromatogram of $\underline{A}$. glabra seed extract)

Tabel(Table) 2. Pengaruh pemberian pakan terhadap mortalitas larva Eurema sp. (Effect of $\underline{\text { A. glabra }}$ seed extract by feeding against Eurema sp. larvae mortality)

\begin{tabular}{crrrrrr}
\hline $\begin{array}{c}\text { Perlakuan konsentrasi } \\
\text { (Concentration treatment })\end{array}$ & \multicolumn{6}{c}{$\begin{array}{c}\text { Persentase mortalitas larva setelah hari ke- } \\
\text { (Larvae mortality after days of) }(\%)\end{array}$} \\
\cline { 2 - 7 }$(\mathrm{mg} / \mathrm{ml})$ & \multicolumn{1}{c}{1} & \multicolumn{1}{c}{2} & \multicolumn{1}{c}{3} & \multicolumn{1}{c}{4} & 5 & \multicolumn{1}{c}{6} \\
\hline 0 & $6,7 \mathrm{a}$ & $6,7 \mathrm{a}$ & $10,0 \mathrm{a}$ & $10,0 \mathrm{a}$ & $23,3 \mathrm{a}$ & $30,0 \mathrm{a}$ \\
3,125 & $50,0 \mathrm{~b}$ & $63,3 \mathrm{~b}$ & $83,3 \mathrm{~b}$ & $86,6 \mathrm{~b}$ & $90,0 \mathrm{~b}$ & $90,0 \mathrm{~b}$ \\
6,25 & $100,0 \mathrm{c}$ & $100,0 \mathrm{c}$ & $100,0 \mathrm{~b}$ & $100,0 \mathrm{~b}$ & $100,0 \mathrm{~b}$ & $100,0 \mathrm{~b}$ \\
12,5 & $96,7 \mathrm{c}$ & $100,0 \mathrm{c}$ & $100,0 \mathrm{~b}$ & $100,0 \mathrm{~b}$ & $100,0 \mathrm{~b}$ & $100,0 \mathrm{~b}$ \\
25 & $90,0 \mathrm{c}$ & $96,7 \mathrm{c}$ & $100,0 \mathrm{~b}$ & $100,0 \mathrm{~b}$ & $100,0 \mathrm{~b}$ & $100,0 \mathrm{~b}$ \\
50 & $96,7 \mathrm{c}$ & $100,0 \mathrm{c}$ & $100,0 \mathrm{~b}$ & $100,0 \mathrm{~b}$ & $100,0 \mathrm{~b}$ & $100,0 \mathrm{~b}$ \\
100 & $96,7 \mathrm{c}$ & $100,0 \mathrm{c}$ & $100,0 \mathrm{~b}$ & $100,0 \mathrm{~b}$ & $100,0 \mathrm{~b}$ & $100,0 \mathrm{~b}$ \\
\hline
\end{tabular}

Keterangan(Remark): Angka pada kolom yang sama diikuti oleh huruf yang sama menunjukkan tidak berbeda nyata pada tingkat nyata $5 \%$ (Values in same column followed by same letters means not significant different in the level $5 \%$ )

Tabel 3 menunjukkan bahwa penyempotan langsung ektrak biji buah nona sebrang ke larva berpengaruh nyata terhadap mortalitas larva pada hari ke-1, 2, 3, 4, 5 dan ke 6. Hasil uji lanjut pada hari pertama menunjukkan bahwa antar konsentrasi $12,5 \mathrm{mg} / \mathrm{ml}, 25 \mathrm{mg} / \mathrm{ml}$ dan 100 $\mathrm{mg} / \mathrm{ml}$ tidak berbeda nyata, tetapi dengan perlakuan konsentrasi kontrol; $6,25 \mathrm{mg} / \mathrm{ml}$ dan $50 \mathrm{mg} / \mathrm{ml}$ berbeda nyata. Penyemprotan dengan dosis $6,25 \mathrm{mg} / \mathrm{ml}$ belum mampu mematikan larva yang signifikan. Namun pada penyemprotan dengan dosis $6,25 \%$ baru efektif terlihat pada hari keenam. 
Tabel (Table) 3. Pengaruh penyemprotan terhadap mortalitas larva Eurema sp. (Effect of $\underline{\text { A. glabra seed }}$ extract by spraying against of Eurema sp. larvae mortality)

\begin{tabular}{|c|c|c|c|c|c|c|}
\hline \multirow{2}{*}{$\begin{array}{c}\text { Perlakuan konsentrasi } \\
\text { (Concentration treatment) } \\
(\%)\end{array}$} & \multicolumn{6}{|c|}{ Mortalitas larva setalah hari ke- (Larvae mortality after days to) $(\%)$} \\
\hline & 1 & 2 & 3 & 4 & 5 & 6 \\
\hline 0 & $6,7 \mathrm{ab}$ & $6,7 \mathrm{a}$ & $10,0 \mathrm{a}$ & $10,0 \mathrm{a}$ & $23,3 \mathrm{a}$ & $30,0 \mathrm{a}$ \\
\hline 6,25 & $0,0 \mathrm{a}$ & $16,7 \mathrm{a}$ & $16.7 \mathrm{a}$ & $46,7 \mathrm{~b}$ & $70,0 \mathrm{~b}$ & $90,0 \mathrm{~b}$ \\
\hline 12,5 & $80,0 \mathrm{c}$ & $83,3 \mathrm{~b}$ & $83,3 \mathrm{~b}$ & $96,7 \mathrm{c}$ & $96,7 \mathrm{c}$ & $100,0 \mathrm{~b}$ \\
\hline 25 & $90,0 \mathrm{c}$ & $90,0 \mathrm{~b}$ & $100,0 \mathrm{~b}$ & $100,0 \mathrm{c}$ & $100,0 \mathrm{c}$ & $100,0 \mathrm{~b}$ \\
\hline 50 & $63,3 \mathrm{~b}$ & $90,0 \mathrm{~b}$ & $100,0 \mathrm{~b}$ & $100,0 \mathrm{c}$ & $100,0 \mathrm{c}$ & $100,0 \mathrm{~b}$ \\
\hline 100 & $70,0 \mathrm{c}$ & $96,7 \mathrm{~b}$ & $100,0 \mathrm{~b}$ & $100,0 \mathrm{c}$ & $100,0 \mathrm{c}$ & $100,0 \mathrm{~b}$ \\
\hline
\end{tabular}

Keterangan(Remark): Angka pada kolom yang sama diikuti huruf yang sama menunjukkan tidak berbeda nyata pada tingkat nyata 5\% (Values in same column followed by same letters means not significantly different in the level $5 \%$
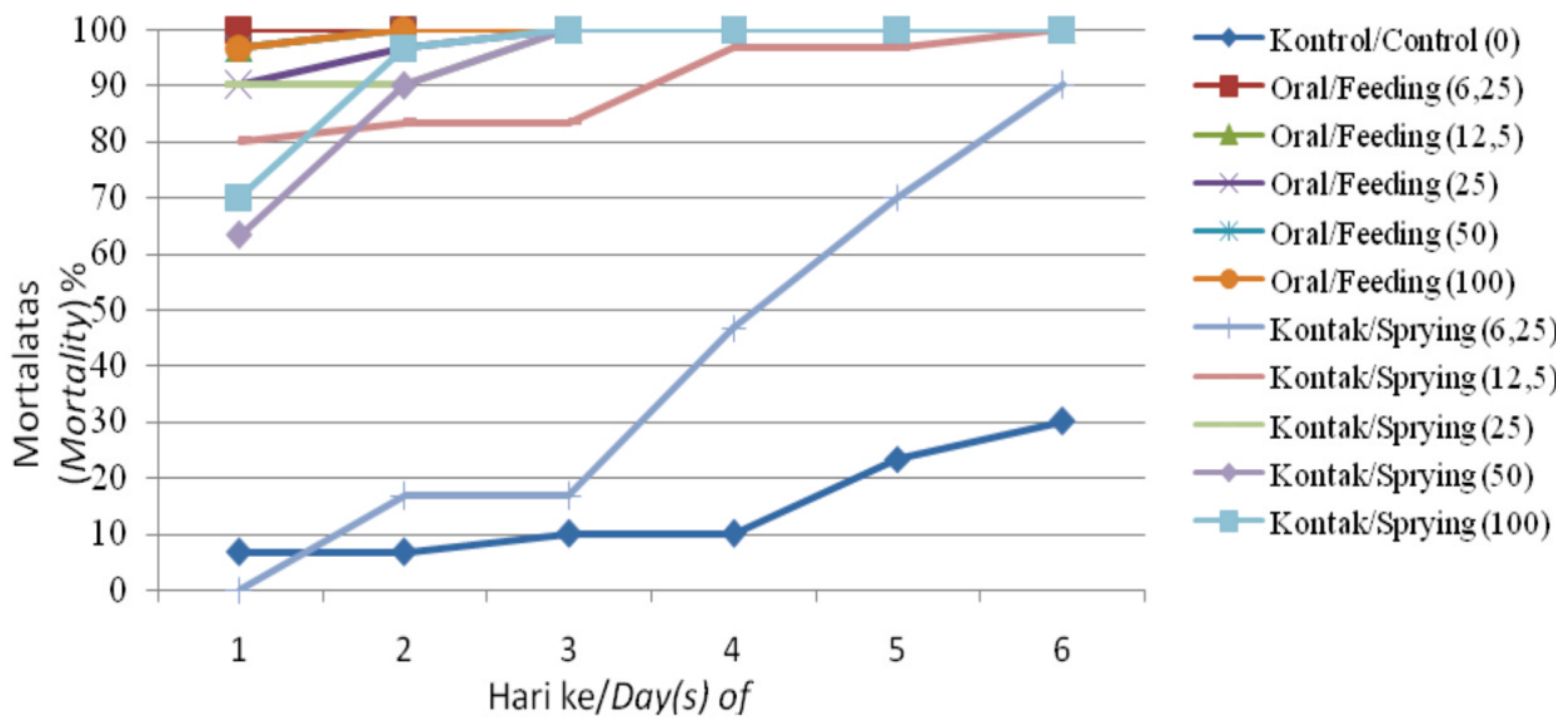

Gambar(Figure) 1. Pengaruh perlakuan pemberian pakan dan penyemprotan ekstrak biji nona sebrang terhadap persentase kematian larva Eurema sp. (Effect of feeding and spraying A. glabra seed extract against mortality percentage of Eurema sp. larvae)

Pada pengujian penyemprotan langsung ke pakan (oral) diperoleh persamaan probit $\mathrm{y}=$ $0,182 \log \mathrm{x}+5,378$, dimana $\mathrm{x}=$ konsentrasi dengan koefisien korelasi 0,56. Dengan demikian nilai $\mathrm{LC}_{50}$ untuk perlakuan penyemprotan pada pakan adalah $8,37 \mathrm{mg} / \mathrm{ml}$. Pada perlakuan penyemprotan langsung ekstrak biji nona sebrang ke larva (kontak tubuh) diperoleh persamaan probit $\mathrm{y}=0,059 \log \mathrm{x}+5,142$ dengan koefisien korelasi 0,22 dan diperoleh nilai $\mathrm{LC}_{50}$ sebesar $3,92 \mathrm{mg} / \mathrm{ml}$.

\section{B. Pembahasan}

Hasil identifikasi senyawa yang terdapat dalam ekstrak biji nona sebrang menunjukkan adanya kandungan senyawa 13-Docosenoic acid atau Erucic acid, asam oleat (oleic acid) 9octadecenoic acid, 3-hexadecyloxycarbonyl -5(2-hydroxyethyl)-4-methylimidazol dan 9octadecenamide.

Senyawa 13-Docosenoic acid atau Erucic acid dan asam oleat (oleic acid) merupakan beberapa senyawa dari kelompok asam lemak. Senyawa-senyawa dari asam lemak dapat berfungsi sebagai anti hama (Reifenrath, 2014). 
Selain itu, senyawa 9-octadecenoic acid (asam oleat) bersifat letal terhadap larva serangga Aedes aegyptii dan Culex pipiens pallens (Imaniar et al., 2013; Perumalsamy et al., 2015). Menurut PérezGutiérrez et al. (2011) asam oleat juga dapat menurunkan daya hidup atau viabilitas serangga hama ulat grayak Spodoptera frugiperda (Lepidoptera: Noctuidae) yang mana hama ini telah menunjukkan bukti-bukti resistensi terhadap pestisida biologi Bacillus thuringiensis (Bt) di Amerika Serikat (Huang et al., 2014).

Adapun golongan senyawa 3-hexadecyloxycarbonyl-5-(2-hydroxyethyl)-4-methylimidazol memiliki aktivitas sebagai fungisida dengan cara kerja menghambat biosintesis sterol pada tahap demetilasi C14 (DMI: C14-demethylation inhibitors). Senyawa 9-octadecenamide tidak secara langsung bersifat anti hama, namun senyawa ini berperan dalam menarik kedatangan musuh alami hama pada saat tanaman tertentu diserang (Rani, 2014). Selain itu senyawa ini juga dapat berperan sebagai antimikroba (Meenakshi etal., 2012).

Pemberian pakan yang diperlakukan pada serangga uji menunjukkan respon mortalitas yang nyata dibandingkan dengan kontrol. Hal ini sudah terlihat pada satu hari setelah perlakuan. Mortalitas semakin meningkat sejalan dengan semakin tingginya konsentrasi yang digunakan dan lamanya pengamatan. Perlakuan menggunakan ekstrak biji nona sebrang dengan konsentrasi lebih dari $6,25 \mathrm{mg} / \mathrm{ml}$ sudah mengakibatkan kematian hampir $100 \%$ pada satu hari setelah perlakuan.

Data ini menunjukkan bahwa jika konsentrasi $6,25 \mathrm{mg} / \mathrm{ml}$ sudah cukup efektif menyebabkan kematian larva Eurema sp. Meskipun belum terlihat pada permulaan, mortalitas akibat perlakuan dengan konsentrasi yang rendah terlihat lebih lambat seperti yang ditunjukkan pada perlakuan $3,125 \mathrm{mg} / \mathrm{ml}$.

Pengaruh nyata perlakuan terhadap mortalitas serangga uji juga ditunjukkan oleh perlakuan yang menggunakan teknik semprot (kontak tubuh). Respon mortalitas yang nyata sudah mulai tampak pada satu hari setelah perlakuan. Meskipun lebih lambat dibandingkan dengan teknik pemberian pakan, teknik kontak tubuh juga menunjukkan hasil yang baik, kecuali perlakuan $6,25 \mathrm{mg} / \mathrm{ml}$.

Perlakuan pemberian pakan dan penyemprotan memberikan pengaruh mortlitas yang berbeda pada larva Eurema sp. Perlakuan pemberian pakan lebih cepat menimbulkan kematian dibandingkan penyemprotan langsung ke larva Eurema sp. Meskipun demikian pada akhir pengamatan, kedua cara penyemprotan tersebut sama-sama efektif menimbulkan kematian larva Eurema sp.

Hasil analisis nilai lethal concentration 50 $\left(\mathrm{LC}_{50}\right)$ yang diperoleh dari perlakuan pemberian pakan adalah sebesar $8.37 \mathrm{mg} / \mathrm{ml}$. Sedangkan pada perlakuan penyemprotan tubuh nilai $\mathrm{LC}_{50}$ adalah sebesar $3,92 \mathrm{mg} / \mathrm{ml}$.

Aktivitas insektisidal ekstrak biji nona sebrang tidak dapat terlepas dari kandungan senyawa kimia yang terdapat di dalamnya. $A$. glabra merupakan salah satu spesies tanaman yang tergolong dalam kelompok famili Annonaceae yang terkenal sebagai penghasil bioinsektisida. Menurut Thang et al. (2013) senyawa yang terdapat pada $A$. glabra adalah $\beta$ caryophyllene, germacrene $D$, $\alpha$-cadinol dan $\beta$ elemene. Senyawa $\beta$-caryophyllene adalah salah satu senyawa yang berasal dari kelompok terpen. Senyawa ini menurut Chaubey (2012) tidak hanya mampu menolak, tetapi juga bersifat letal terhadap serangga Tribolium castaneum Herbst (Coleoptera: Tenebrionidae) bahkan pada konsentrasi yang rendah. Adapun senyawa terpen lainnya, germacrene $D$ dan $\alpha$-cadinol juga dilaporkan bersifat toksit terhadap larva Anopheles subpictus, Aedes albopictus dan Culex tritaeniorhynchus (Pavela \& Govindarajan, 2016). $\beta$-elemene juga bersifat anti serangga khusunya dari kelompok Diptera seperti lalat kotoran, lalat penghisap darah dan nyamuk menolak serangga dengan cara menolak (repell) (Zhang et al., 2011).

Diantara kandungan kimia yang ditemukan dalam bagian tanaman ini adalah acetogenin (Krinski et al., 2014). Senyawa acetogenin juga dapat dijumpai pada ekstrak biji tumbuhan Annonaceae lainnya seperti Annona mucosa sebagai acetogenin rolliniastatin-1. Senyawasenyawa ini bersifat toksit, penolak aktivitas makan bahkan bertelur dari hama kutu Diaphorina citri (Hemiptera: Liviidae). Efektivitasnya bahkan telah teruji baik di skala pesemaian maupun operasional (Ribeiro et al., 2015).

Menyerupai rotenone, senyawa acetogenin bekerja dengan mekanisme peracunan pada proses sintesa energi dalam mitokondria sel. Senyawa squamocin menurunkan Adenosine Triphosphate (ATP) melalui gangguan rantai respirasi yang selanjutnya memicu terjadinya kematian sel (Costa et al., 2014). Sementara itu sel yang terpengaruh oleh senyawa acetogenin dari kelompok asimicin menunjukkan gejala ber- 
kurangnya konsumsi oksigen. Dengan demikian bahwa asimicin menyebabkan terganggunya konsumsi oksigen dalam sel, sehingga memicu kematian(El-Wakeil, 2013).

Ekstrak yang diberikan melalui pemberian pakan dan penyemprotan pada tubuh serangga uji menunjukkan tingkat efektivitas yang sama baiknya. Kecuali pada konsentrasi $6,25 \mathrm{mg} / \mathrm{ml}$, perlakuan penyemprotan menunjukkan tidak berbeda nyata sampai pada hari ke empat. Pada hari pertama terdapat variasi tingkat mortalitas yang tinggi dan cenderung tidak konsisten dengan kenaikan konsentrasi ekstrak khususnya pada penyemprotan dengan konsentrasi 50 $\mathrm{mg} / \mathrm{ml}$. Variasi (tidak konsistennya) tingkat mortalitas terhadap konsentrasi juga pernah dilaporkan oleh Sujak \& Diana (2012) pada serangga uji Aphis gossypii Glover (Homoptera; Aphididae) yang diperlakukan menggunakan ekstrak nikotin dari daun tembakau pada konsentrasi rendah. Namun demikian, pada pengamatan hari kedua sampai hari keenam terjadi konsistensi kenaikan tingkat mortalitas yang sejalan dengan tingkat konsentrasi larutan ekstrak biji nona sebrang yang digunakan.

\section{KESIMPULAN DAN SARAN}

\section{A. Kesimpulan}

Senyawa 9-octadecenoic acid (asam oleat) dan 13-Docosenoic acid atau Erucic acid merupakan senyawa aktif utama yang terdapat pada ekstrak biji nona sebrang (A. glabra). Senyawa tersebut secara nyata bersifat toksit sehingga mampu mempengaruhi tingkat mortalitas larva serangga Eurema sp. Senyawa tersebut dapat bekerja secara oral dan juga bisa juga berfungsi sebagai racun kontak. Konsentrasi larutan yang dibutuhkan untuk menyebabkan kematian sampai 50\% serangga uji (nilai lethal concentration, $\mathrm{LC}_{50}$ ) masing-masing untuk perlakuan pemberian pakan dan penyemprotan adalah $8,37 \mathrm{mg} / \mathrm{ml}$ dan $3,92 \mathrm{mg} / \mathrm{ml}$.

\section{B. Saran}

Pengendalian hama dengan menggunakan insektisida nabati terutama dari ekstrak biji nona sebrang perlu sosialisasikan kepada masyarakat karena insektisida tersebut berdampak kecil terhadap lingkungan. Hasil penelitian ini perlu diujikan di tingkat lapangan guna menguji formula yang efektif.

\section{UCAPAN TERIMA KASIH}

Terima kasih kepada Ridwan yang telah membantu dalam mengumpulkan material berupa larva serangga Eurema sp. yang selanjutnya digunakan dalam penelitian ini.

\section{DAFTAR PUSTAKA}

BPS [Badan Pusat Statistik]. (2013). Sensus pertanian, sub sektor kehutanan. http://st2013.bps.go.id/dev2/index.php/site/ tabel? tid $=65 \&$ wid $=0$. Diakses 23 April 2015.

Chaubey, M.K. (2012). Acute, lethal and synergistic effects of some terpenes against Tribolium castaneum Herbst (Coleoptera: Tenebrionidae). Ecologia Balkanica, 4(1), 5362.

Costa, M.S., Cossolin, J.F.S., Pereira, M.J. B., Sant'Ana, A.E. G., Lima, M.D., Zanuncio, J.C., \& Serrão, J.E. (2014). Larvicidal and cytotoxic potential of squamocin on the midgut of Aedes aegypti (Diptera: Culicidae). Toxins, 6,1169-1176.

De Oliveira, F.Q., Batista, J.D.L., Malaquias, J.B., Almeida, D.M., \& De Oliveira, R. (2010). Determination of the median lethal concentration (LC50) of mycoinsecticides for the control of Ceratitis capitata (Diptera: Tephritidae). Revista Colombiana de Entomología, 36(2), 213-216.

El-Wakeil, N.E. (2013). Botanical pesticides and their mode of action. Gesunde Pflanzen, 65, 125149.

Huang, F., Qureshi, J.A., Meagher, J.R.L., Reisig, D.D., Head, G.P., Andow, D.A., Ni, X., Kerns, D., Buntin, G.D., Niu,Y., Yang, F., \& Dangal, V. (2014). Cry1F resistance in fall armyworm Spodoptera frugiperda: single gene versus pyramided bt maize. PLoS ONE, 9(11), e112958 doi:10.1371/journal.pone.0112958.

Imaniar, R., Latifah, \& Sugiyo, W. (2013). Ekstraksi dan karakterisasi senyawa bioaktif dalam daun kenikir (Cosmos sulphureus) sebagai bahan bioinsektisida alami. Indonesian Journal of Chemical Science, 2(1), 51-55. http://journal.unnes.ac.id/sju/index.php/ijcs.

Krinski, D., Massaroli, A., \& Machado, M. (2014). Insecticidal potential of the annonaceae family plants. Revista Brasileira De Fruticultura, 36(1), 225-242.

Meenakshi, V.K., Gomathy, S., Senthamarai, S. Paripooranaselvi, M., \& Chamundeswari, K.P. (2012). GC-MS determination of the bioactive 
components of Microcosmus exasperatus Heller, 1878. Journal of Current Chemical Pharmaceutical Sciences, 2(4), 271-276.

Ogah, E.O., \& Ogbodo, E.N. (2012). Comparative efficacy of neem seed extract with carbofuran in the management of african rice gall midge, Orseolia oryzivora Harris and Gagne (Diptera: Cecidomyppdae). Journal of Biology, Agriculture and Healthcare, 2(5), 147-153.

Pavela, R., \& Govindarajan, M. (2016). The essential oil from Zanthoxylum monophyllum a potential mosquito larvicide with low toxicity to the non-target fish Gambusia affinis. Journal of Pest Sciences, 1-10. doi:10.1007/s10340-0160763-6.

Pérez-Gutiérrez, S., Zavala-Sánchez, M.A., González-Chávez, M.M., Cárdenas-Ortega, N.C., \& Ramos-López, M.A. (2011). Bioactivity of Carica papaya (Caricaceae) against Spodoptera frugiperda (Lepidoptera: Noctuidae). Molecules, 16, 7502-7509.

Perumalsamy, H., Jang, M.J., Kim, J.R., Kadarkarai, M., \& Ahn, Y.J. (2015). Larvicidal activity and possible mode of action of four flavonoids and two fatty acids identified in Millettia pinnata seed toward three mosquito species. Parasites \& Vectors, 8(237), 1-14.

Rani, U.P. (2014). Kairomones for Increasing the Biological Control Efficiency of Insect Natural Enemies. In: Sahayaraj, K. (Ed.). (2014). Basic and applied aspects of biopesticides. Springer, New Delhi.

Reifenrath, W. (2014). US Application patent No $13 / 264,238$
Ribeiro, L.D.P., Santos, M.S., Gonçalves, G.L.P., \& Vendramim, J.D. (2015). Toxicity of an acetogenin-based bioinsecticide against Diaphorina citri (Hemiptera: Liviidae) and its parasitoid Tamarixia radiata (Hymenoptera: Eulophidae). Florida Entomologist, 98(3), 835-842.

Sujak, \& Diana, N.E. (2012). Uji efektifitas ekstrak nikotin formula 1 (pelarut ether) terhadap mortalitas Aphis gossypii (Homoptera; Aphididae). Agrovigor, 5(1), 47-51.

Thang, T.D., Dai, D.N., Hoi, T.M. \& Ogunwande, I.A. (2013). Study on the volatile oil contents of Annona glabra L., Annona squamosa L., Annona muricata L. and Annona reticulata L., from Vietnam. Natural Product Research, 27(13), 1232-1236.

Tuhumury, A. (2007). Inventarisasi jenis hama pada tanaman sengon (Paraserianthes falcataria Nielson) di lokasi Hutan Kemasyarakatan Waesamu, Kecamatan Kairatu, Kabupaten Seram Bagian Barat. Jurnal Agroforestri, 2(1), 13-18.

Utami, S. (2010). Aktivitas insektisida Bintaro (Cerbera odollam Gaertn) terhadap hama Eurema spp. pada skala laboratorium. Jurnal Penelitian Hutan Tanaman, 7(4), 211-220.

Zhang, Q., Margaryan, A., \& Schneidmiller, R.G. (2011). Methods for repelling insects using sesquiterpene hydrocarbons and their derivatives. Paten Nomor US 8057829 B2.

Zhu, W., Schmehl, D.R., Mullin, C.A., \& Frazier, J.L. (2014). Four common pesticides, their mixtures and a formulation solvent in the hive environment have high oral toxicity to honey bee larvae. PLoS ONE, 9(1), 1-11. 